Science and Humanities Journal

Vol. 10, 2013, pp. 1-15 Dol: https://doi.org/10.47773/shj.1998.101.1

\title{
EFFECTS OF CULTURED YEAST SUPPLEMENTATION ON GROWING KIDS FED WITH NAPIER GRASS- CONCENTRATE RATION
}

\author{
Mark V. Abela ${ }^{1}$ and Lolito C. Bestil ${ }^{2}$ \\ ${ }^{1}$ Instructor and ${ }^{2}$ Professor \\ Department of Animal Science, Visayas State University, \\ Visca, Baybay City 6521-A Leyte, Pbilippines
}

\begin{abstract}
An in vivo experiment was conducted to assess the effects of live yeast supplementation on the performance of six-month-old young goats. Specifically, it investigated the effects of cultured yeast (Saccharomyces cerevisiae) supplementation on the dry matter intake, growth performance, fluctuation in ruminal fluid $\mathrm{pH}$ and rumen bacterial count, as well as on the digestibility of dry matter, organic matter, and crude protein of the napier grass-concentrate ration.

The addition of cultured yeast at two grams $/ 10 \mathrm{~mL}$ distilled water generally increased dry matter intake and weight gain of the young goats, but did not significantly affect bacterial count and ruminal fluid $\mathrm{pH}$. The digestibility of dry matter, organic matter, and crude protein of the napier grass-concentrate ration increased with the addition of cultured yeast. Yeast supplementation of one gram $/ 10 \mathrm{~mL}$ distilled water enhanced nutrient intake and utilization of the napier grass-concentrate ration.
\end{abstract}

Key words: small ruminants, ruminal $\mathrm{pH}$, bacterial count, digestibility 


\section{INTRODUCTION}

Ruminant animals are unique due to their four-compartment stomach and their ability to digest the otherwise indigestible, highly fibrous feedstuff (Scanes, 2011). They have evolved from animals that feed on mixed, poor-quality grazing and have developed a rumen which is a huge, unwieldy and biologically complex organ that allows ruminants to extract energy and protein from otherwise indigestible plant material (Bazeley and Alaistair, 2007).

The quality of forage greatly affects its consumption. Highquality forage is more digestible and passes through the digestive tract more rapidly than low-quality forage; hence, animals consume more of it (Tyler and Ensminger, 2006). The feeding of concentrate supplement to improve the utilization of the basal roughage diet gives positive results in maximizing voluntary intake of the basal diet and in increasing weight gain (Solaiman, 2010). However, the amount to be added has a limit so as to prevent "substitution effect" where voluntary intake of the basal diet starts to decline (Farmer et al., 2001; Poppi and Mclennan, 1995).

When a higher level of production is desired such as in growing animals, other forms of dietary manipulation must be adopted to further improve rumen function. In effect, studies have been directed toward designing more efficient utilization of low quality feedstuff through feeding of probiotics (microorganisms that when fed to the animal have a positive impact on the host by improving gastrointestinal tract microbial balance) such as Lactobacillus and Bacillus which stimulate more efficient fermentation and foster weight gain (Lasley, 1981).

Feeding live yeast (Saccharomyces cerevisiae) to ruminants has been empirically known to improve productivity, health and well-being by optimizing the fermentation conditions of the rumen. It has the ability to improve rumen conditions, fermentation and function (Ziggers, 2011; Hassanein and Soliman, 2010; Fortina et al., 2011) and the major benefits of adding yeast is to stabilize ruminal $\mathrm{pH}$, reduce the risk of sub-acute acidosis, and improve the animal's performance (increase the milk and milk solids yield) by improving 
feed efficiency, increasing fiber digestion, and especially improving utilization of the least degradable fraction of the fiber component (Mazzia and Walker, 2008).

Due to rising costs of feed concentrates, animal raisers try to optimize the value of the diet. Studies on feeding yeast to ruminants were basically established for large ruminants and there is scarce information on adding live yeast to growing kids' diet in the tropics particularly in the Philippines. Hence, this study explored the potential of cultured baker's yeast (Saccbaromyces cerevisiae) supplementation on feed utilization and performance of young growing goats.

\section{MATERIALS AND METHODS}

Live yeast cells were inoculated onto nutrient agar medium $(10 \mathrm{~mL}$ potato dextrose agar/petri plate) incubated and observed for three to five days. The cultured yeast was harvested and used as supplement during the morning feeding of the young goats by diluting it with distilled water at $10 \mathrm{~mL} /$ unit weight according to the treatments before drenching.

Ziggers (2011); El-Waziry and Ibrahim (2007); and Auclair (2002), revealed that feeding live yeast to cattle at non-nutritional levels $(0.5-20 \mathrm{~g} /$ day $)$ affected the bacterial population in the rumen which resulted to an increase in microbial protein and fiber degradation as well as an increase in bacterial count of more than $130 \%$. Twelve four to six-month-old growing kids were randomly distributed into the following treatments: one (1) gram cultured yeast in $10 \mathrm{~mL}$ distilled water given at $2 \mathrm{~mL} / \mathrm{head} /$ day; three grams cultured yeast in $10 \mathrm{~mL}$ distilled water given at $2 \mathrm{~mL} / \mathrm{head} /$ day, and an unsupplemented control. The three treatments were arranged following a randomized complete block design with four replications per treatment.

The animals were adjusted to their diet for 10 days prior to yeast supplementation. They were fed with napier grass (Pennisetum purpureum, Sch.) basal diet at ad libitum and a concentrate mix at one percent of the body weight. Feeding was done twice per day at 8:30 in the morning and 4:00 in the afternoon. Cultured yeast supplement was 
given between 6:30 to 8:30 A.M. daily by drenching. The concentrate mix was formulated to provide the nutrients required by the animal not sufficiently supplied by the forage (Tables 1 and 2).

Table 1. Composition of the concentrate ration (as-fed) used in this experiment for growing kids

\begin{tabular}{lcc}
\hline Ingredients & Parts as fed (kg) & Amount as fed (\%) \\
\hline Yellow corn & 99.40 & 87.68 \\
Fish meal & 4.64 & 4.09 \\
Rice Bran & 9.25 & 8.16 \\
Salt & 0.08 & 0.07 \\
\hline Total & 113.37 & 100.00 \\
\hline \hline
\end{tabular}

Table 2. Amount of nutrients supplied by roughage and concentrate mix based on the requirements of the growing kids

\begin{tabular}{lccccc}
\hline Feed & $\begin{array}{c}\text { Amount } \\
(\mathrm{kg}, \mathbf{D M})\end{array}$ & $\begin{array}{c}\text { TDN } \\
(\mathbf{k g})\end{array}$ & $\begin{array}{c}\text { CP } \\
(\mathrm{g})\end{array}$ & Ca (g) & $\begin{array}{c}\text { Total P } \\
(\mathrm{g})\end{array}$ \\
\hline Napier grass & 0.30600 & 0.1700 & 29.07 & 1.28 & 1.19 \\
Yellow corn & 0.08208 & 0.0710 & 6.40 & 0.06 & 0.20 \\
Fish meal & 0.00400 & 0.0031 & 2.56 & 0.16 & 0.11 \\
Rice Bran, $D_{1}$ & 0.00800 & 0.0062 & 0.99 & 0.01 & 0.12 \\
Salt & 0.00008 & - & - & - & - \\
\hline \multicolumn{1}{c}{ Total } & 0.40016 & 0.25 & 39.00 & 1.51 & 1.62 \\
\hline $\begin{array}{l}\text { Requirements } \\
\text { (PHILSAN,2003) }\end{array}$ & 0.40 & 0.25 & 39.00 & 1.50 & 1.20 \\
\hline
\end{tabular}

Voluntary intake and growth measurement, including fluctuations in ruminal $\mathrm{pH}$ and bacterial count, were monitored for three months, followed by a five-day digestibility trial for some nutrients in the feed. Bacterial counting was limited to colony forming units (cfu/mL).

The in vivo digestibility of the feeds was measured using opentop metabolism cages allowing separation of the feces from the urine (Bestil, 1985; Bestil and Espina, 1992). The digestibility measurements were conducted at $90 \%$ of ad libitum intake to ensure that the woody tissues present in the forage were taken in and included in the measurement (Bestil, 2009). Samples of feed and feces were collected daily and stored in a freezer for subsequent analyses. 
The analyses of nutrients were done in duplicates at the Nutrition Laboratory of the Department of Animal Science, College of Agriculture and Food Science, Visayas State University using the procedures of the Association of Official Analytical Chemists (1990).

\section{Data Gathering and Analysis}

Ruminal fluid was collected using a stomach tube (Ch 18, 125 $\mathrm{cm})$. The rumen $\mathrm{pH}$ was determined using a digital "JENCO" pen-type $\mathrm{pH}$ meter reader once a month, two hours before and two hours after feeding the animals in the morning. Rumen bacterial count was determined before the start of cultured yeast supplementation at seven days and 14 days after yeast supplementation, expressed as colony forming units per milliliter rumen fluid (cfu/mL).

Rumen fluid samples were serially diluted and placed in nutrient agar and incubated in an airtight chamber. Colonies formed after the incubation period of 18-24 hours were counted and used as the basis for comparison of the dietary treatments.

The data were analyzed using two-way ANOVA, and treatment means were compared by Tukey's Honestly Significant Difference (HSD) Test using Statistical Package for Social Sciences (SPSS), version 16.

\section{RESULTS AND DISCUSSION}

\section{A. Growth Performance}

\section{Cumulative voluntary dry matterintake (CVDMI)}

The cumulative dry matter intake of the goats supplemented with different levels of cultured yeast fed with napier grass-concentrate ration as presented in Table 3 shows significant differences during the second and third month, and those supplemented with cultured yeast, either one gram or three grams were significantly higher than those 
having none. The insignificant differences in the first month may have been an effect of stress. Goats are highly sociable animals; such that, isolating them from the group increases stress levels, particularly if they are unable to maintain visual contact with other goats (Pond and Bell, 2005).

Table 3. Cumulative dry matter intake of growing kids fed with napier grass-concentrate ration supplemented with different levels of cultured yeast

\begin{tabular}{lccc}
\hline \multirow{2}{*}{ Treatment } & \multicolumn{3}{c}{ Cumulative DM intake (kg) } \\
\cline { 2 - 4 } & $\mathbf{1}^{\text {st }}$ month & $\mathbf{2}^{\text {nd }}$ month & $\mathbf{3}^{\text {rd }}$ month \\
\hline Control (Without veast) & 5.29 & $7.09^{\mathrm{b}}$ & $8.22^{\mathrm{b}}$ \\
1 g yeast in 10 ml water & 5.68 & $7.73^{\mathrm{a}}$ & $9.41^{\mathrm{a}}$ \\
3 g veast in 10 ml water & 5.60 & $7.62^{\mathrm{ab}}$ & $9.58^{\mathrm{a}}$ \\
\hline$p$-value & 0.323 & 0.038 & 0.003 \\
\hline \hline
\end{tabular}

Means within a column of similar letter superscripts are not significantly different

The higher voluntary dry matter intake of goats with yeast supplement (either 1 or 3 grams) compared to that of the control group may be due to improved microbial protein supply and fiber degradation, as voluntary intake and digestibility are positively correlated (Newbold and Hillman, 2004). Yeast enhances the growth of beneficial microorganisms that help in stabilizing and stimulating rumen digestion, consequently increasing dry matter intake (Mosoni et al., 2007; Denev et al., 2007; Newbold and Hillman, 2004; Newbold, 1996; and Wallace, 1994). Therefore, in terms of voluntary dry matter intake, greater advantage can be accomplished when goats receive yeast supplementation.

\section{Cumulative weight gain $(C W G)$}

Cumulative weight gain as affected by supplementation of yeast showed significant differences among treatments (Table 4). The animals supplemented with cultured yeast were significantly heavier than those without yeast supplementation. In addition, animals supplemented with three grams cultured yeast had increasingly better 
weight gains than those receiving only one gram yeast, indicating that higher levels of yeast supplementation had a positive effects on the growth performance of the young goats.

Table 4. Cumulative weight gain of growing kids fed with napier grass-concentrate ration supplemented with different levels of cultured yeast

\begin{tabular}{lccc}
\hline \multirow{2}{*}{ Treatment } & \multicolumn{3}{c}{ Cumulative weight gain (kg) } \\
\cline { 2 - 4 } & $\mathbf{1}^{\text {st }}$ month & $2^{\text {nd }}$ month & $3^{\text {rd }}$ month \\
\hline Control (Without yeast) & $0.45^{\mathrm{b}}$ & $1.25^{\mathrm{b}}$ & $2.80^{\mathrm{b}}$ \\
1 g veast with $10 \mathrm{ml}$ water & $0.90^{\mathrm{a}}$ & $2.00^{\mathrm{ab}}$ & $3.20^{\mathrm{b}}$ \\
3 g yeast with $10 \mathrm{ml}$ water & $1.05^{\mathrm{a}}$ & $2.05^{\mathrm{a}}$ & $4.50^{\mathrm{a}}$ \\
\hline p-vahe & 0.001 & 0.031 & 0.006 \\
\hline Means wilhin a columm of similar letter superscripts are not significantly different
\end{tabular}

The results showed a similar pattern of differences in the dry matter intake of the animals as influenced by yeast supplementation. While supplements that provide missing nutrients generally increase digestibility of forage and thereby increase the rate of body weight gain (Solaiman, 2010), those that enhance the growth and multiplication of the bacterial population in the reticulo-rumen do the same (Mosoni et al., 2007; Denev et al., 2007; Newbold and Hillman, 2004; Newbold, 1996; and Wallace, 1994). Yeast acts on the different levels of the fiber digestion process which results to improved fiber digestion (Durand and Durand, 2009; Mazzia and Walker, 2008; and Cole et al., 1992) and consequently improved voluntary intake and weight gain.

\section{B. Rumen Characteristics}

\section{RuminalpH}

No significant differences in ruminal $\mathrm{pH}$ of the animals were observed two hours after feeding (Table 5). However, the effect of yeast on ruminal $\mathrm{pH}$ can be observed two hours before feeding indicating increased production and flow of saliva into the reticulorumen. 
Table 5. Rumen fluid $\mathrm{pH}$ of growing kids fed with napier grass-concentrate ration supplemented with different levels of cultured yeast

\begin{tabular}{|c|c|c|c|c|c|c|c|c|c|c|}
\hline \multirow{3}{*}{ Treatment } & \multicolumn{10}{|c|}{ Ruminal oH ( 2 hrs before and after feeding) } \\
\hline & \multicolumn{2}{|c|}{$\begin{array}{c}\text { Initial } \\
\text { (Sept 14) } \\
\text { (conditioning } \\
\text { time) }\end{array}$} & \multicolumn{2}{|c|}{$\begin{array}{l}\text { Initial (late } \\
\text { Sept) } \\
\text { (with } \\
\text { supplementation) }\end{array}$} & \multicolumn{2}{|c|}{ 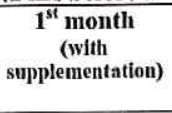 } & \multicolumn{2}{|c|}{$\begin{array}{c}2^{\text {nd }} \text { month } \\
\text { (wlth } \\
\text { supplementation) }\end{array}$} & \multicolumn{2}{|c|}{$\begin{array}{c}3^{\text {rd }} \text { month } \\
\text { (with } \\
\text { supplementation) }\end{array}$} \\
\hline & before & after & before & after & before & after & before & after & before & after \\
\hline Control & 7.2 & 7.3 & $6.4^{b}$ & 6.5 & $6.3^{\mathrm{b}}$ & 6.4 & $6.3^{\mathrm{b}}$ & $6.4^{\mathrm{b}}$ & $6.3^{6}$ & $6.3^{b}$ \\
\hline $\begin{array}{l}\text { With } 1 \\
\text { gram yeast }\end{array}$ & 7.1 & 7.2 & $6.6^{\mathrm{ab}}$ & 6.7 & $6.6^{\mathrm{a}}$ & 6.5 & $6.5^{\mathrm{ab}}$ & $6.6^{\mathrm{bb}}$ & $6.5^{\mathrm{ab}}$ & $6.6^{\mathrm{th}}$ \\
\hline $\begin{array}{l}\text { With } 3 \\
\text { grams yeast }\end{array}$ & 7.2 & 7.3 & $6.7^{\mathrm{a}}$ & 6.7 & $6.7^{\mathrm{a}}$ & 6.6 & $6.7^{\mathrm{a}}$ & $6.8^{\mathrm{a}}$ & $6.6^{\mathrm{a}}$ & $6.7^{3}$ \\
\hline p-value & 0.113 & $\begin{array}{l}0.6 \\
14\end{array}$ & 0.038 & 0.072 & 0.004 & 0.098 & 0.011 & 0.007 & 0.040 & 0.045 \\
\hline
\end{tabular}

Means within a columm of similar letter superscripts are not significantly different

The primary function of saliva is to provide a copious and continuous supply of alkaline buffers to counterbalance the volatile fatty acids produced during fermentation and to provide an aqueous suspension for rumen solids (Solaiman, 2010). Secondary functions include urea recycling as a source of non-protein nitrogen (NPN) for microbial protein synthesis and phosphate for synthesis of microbial nucleic acid and membrane phospholipids (Křižova et al., 2011; and Solaiman, 2010). Apparently, the supplementation of yeast that improved fiber digestion also elicited higher saliva production and increased recycling of urea and phosphates resulting to increased $\mathrm{pH}$ levels.

\section{Rumen bacterial count}

Results on rumen bacterial count showed no significant differences among the levels of yeast added to the diet (Table 6), although numerically, it can be observed that supplementation of yeast to animals seemed to promote increase in rumen bacterial population. 
Table 6. Rumen bacterial count (efu/mL) in growing kids fed with napier grassconcentrate ration supplemented with different levels of cultured yeast

\begin{tabular}{lccc}
\hline \multirow{2}{*}{ Treatment } & \multicolumn{3}{c}{ Rumen bacterial count (cfu/mL) } \\
\cline { 2 - 4 } & $\begin{array}{c}\text { Before } \\
\text { supplementation }\end{array}$ & $\begin{array}{c}\text { 1 week after } \\
\text { supplementation }\end{array}$ & $\begin{array}{c}\text { 2 weeks after } \\
\text { supplementation }\end{array}$ \\
\hline Control (Without yeast) & $4.42 \times 10^{5}$ & $3.56 \times 10^{5}$ & $3.27 \times 10^{5}$ \\
With 1 gram yeast) & $6.12 \times 10^{5}$ & $6.36 \times 10^{5}$ & $6.17 \times 10^{5}$ \\
With 3 grams yeast) & $7.54 \times 10^{5}$ & $9.41 \times 10^{5}$ & $9.35 \times 10^{5}$ \\
\hline p-value & 0.811 & 0.455 & 0.435 \\
\hline Means within a coltumn without letter superscripts are not significantly diffeet
\end{tabular}

Means within a coltumn without letter superscripts are not significantly different

\section{Digestibility}

Digestibility is a measure of the disappearance of a nutrient from the digestive tract, and is assumed to equate with the degree of absorption of the nutrient from the gut lumen (Pond and Bell, 2005). Apparent digestibility is the difference between the amount of a nutrient consumed and the amount excreted in the feces, expressed as proportion of the intake. Unlike true digestibility, apparent digestibility ignores losses of endogenous origin (Fuller et al., 2004).

The digestibility coefficient of dry matter were significantly different among treatments $(\mathrm{P}<0.002)$. Yeast supplementation promoted better dry matter digestion. Fermentation occurring in the reticulo-rumen is achieved through the action of microbial enzymes produced by rumen microorganisms. Yeast scavenges residual oxygen and improves bacterial viability which, in turn, increases the rate of cellulolysis and the flow of microbial protein into the intestines, consequently improving animal productivity (Mosoni et al., 2007; Denev et al., 2007; Pond and Bell, 2005; Newbold and Hillman, 2004; Newbold, 1996; and Wallace, 1994). 
Table 7. Apparent digestibility of mutrients in growing kids fed with napier grassconcentrate ration supplemented with different levels of cultured yeast

\begin{tabular}{lccc}
\hline Treatment & $\begin{array}{c}\text { DM } \\
\text { Digestibility } \\
(\%)\end{array}$ & $\begin{array}{c}\text { OM } \\
\text { Digestibillty } \\
(\%)\end{array}$ & $\begin{array}{c}\text { CP } \\
\text { Digestibillty } \\
(\%)\end{array}$ \\
\hline Control (Without yeast) & $63.44^{\mathrm{b}}$ & $33.45^{\mathrm{b}}$ & $65.49^{\mathrm{b}}$ \\
With 1 gram yeast & $74.45^{\mathrm{a}}$ & $54.69^{\mathrm{a}}$ & $77.93^{\mathrm{a}}$ \\
With 3 grams yeast & $75.51^{\mathrm{a}}$ & $57.34^{\mathrm{a}}$ & $79.08^{\mathrm{a}}$ \\
\hline$p$-yalue & $\mathbf{0 . 0 0 2}$ & $\mathbf{0 . 0 0 0}$ & $\mathbf{0 . 0 0 0}$ \\
\hline Means within a columm of similar letter superscripts are not significantly different
\end{tabular}

Organic matter digestibility likewise showed significant differences among treatments $(\mathrm{P}<0.000)$. Addition of yeast supplement at any level improved organic matter digestibility compared to the unsupplemented control.

A similar trend was also observed on the digestibility coefficient of protein. Animals receiving yeast supplementation had higher crude protein digestibility coefficient than those without $(\mathrm{P}<0.000)$.

The increase in digestibility may have been duc to an improved activity of rumen cellulolytic and some proteolytic bacteria. The addition of yeast stimulates the growth of some anaerobic bacteria, including the cellulolytic and the lactic acid utilizing bacteria (Hassanein and Soliman, 2010). Furthermore, yeast uses the residual oxygen and stabilizes the ruminal $\mathrm{pH}$, creating optimal conditions for the fibrolytic microflora (Mazzia and Walker, 2008) which results to the production of nutrients and co-factors $(B$ vitamins and amino acids) that are essential to the development of numerous microflora, thus, improving fiber digestion. Yeast also helps prevent the decrease in ruminal $\mathrm{pH}$ associated with feeding a cereal based diet (Ahmed and Salah, 2002).

Apparent protein digestibility is a simple measure of the difference between dietary protein intake and protein in the analyzed digesta, which also includes endogenous protein secreted into the gut during digestion (Fuller et al., 2004). Crude protein is usually divided into two types: rumen-degradable protein (RDP) and undegradable 
dietary protein (UDP) which is not digested by the rumen (Vincent, 2005). Microbial protein synthesis in the rumen requires both a nitrogen source and available energy. Most cellulolytic bacteria require ammonia for growth while amylolytic bacteria may require amino acids. When forage is low in protein content or availability, additional protein supplements are needed for maximum production or performance (Solaiman, 2010). Protein contains the nitrogen needed by the ruminal microorganisms to manufacture their own protein consisting of the amino acids, which are later digested by the animal in the lower gut.

Yeast has the potential to reduce the risk of rumen acidosis and increases utilization of metabolizable energy available from low quality diet (Guedes et al., 2008). In addition, yeast culture improves the digestibility of most nutrients through increased net digestion in the forestomach, particularly of fiber leading to increased energy output (Ahmed and Salah, 2002). Furthermore, yeast supplementation significantly improved DM intake, VFA's, and the digestibility of crude protein and acid detergent fiber (Helal and Abdel-Rahman, 2010; Robinson, 2009; Dann et al., 2000; Wohlt et al., 1998; and Wohlt et al., 1991). There is, therefore, an added benefit of increased digestibility of nutrients with the supplementation of yeast in ruminant fed forage-concentrate ration.

\section{CONCLUSION AND RECOMMENDATIONS}

Yeast supplementation of at least one gram in $10 \mathrm{~mL}$ distilled water, increased ruminal $\mathrm{pH}$ necessary for the growth and metabolism of cellulolytic bacteria which, in turn, increased dry matter intake and promoted better weight gains in young growing kids. Furthermore, the addition of yeast supplement in the diet promoted better digestibility of nutrients in the basal diet including fiber digestion. However, further research is needed to develop methods for the mass production and storage of this fungal supplement and its use in practical feeding of animals. 


\section{LITERATURE CITED}

AHMED, B.M. and M. S. SALAH. 2002. Effect of Yeast Culture as an Additive to Sheep Feed on Performance, Digestibility, Nitrogen Balance and Rumen Fermentation. Jour. King Saud Univ. Agric. Sci. 14(1): 1-13

AOAC (Association of Official Analytical Chemists). 1990. Official Method of analysis of AOAC.14th Ed. W. Horwitz (Editor). Allengton, Washington D. C. 73:953

BAZELEY, K. and H. ALAISTAIR. 2007. Practical Cattle Farming. The Crowood Press Limited. p. 77

BESTIL, L. C. 1985. Supplementation of $\mathrm{Ca}(\mathrm{OH} 2)$-treated wheat straw for sheep. MS Thesis. School of Agric. and Forestry. The Univ. of Melbourne, Victoria, Australia

BESTIL, L. C. 2009. Madre de Agua (Tricanthera gigantea, Nees) Supplementation to improve in vivo Basal diet digestion in sheep. Ph. D. Dissertation. Visayas State University, Baybay City, Leyte

BESTIL, L. C. and D. M. ESPINA. 1992. Intake and digestibility of fresh and dried forages from some adaptable legume species. Phil. Jour. Vet. Anim. Sci. 18(2) 137-150

COLE, N. A., C. W. PURDY and D. P. HUTCHESON. 1992. Influence of yeast culture on feeder calves and lambs. Jour. Anim. Sci. 70:1682-1690

DANN, H. M., J. K. DRACKLEY, G. C. MCCOY, M. F. HUTJENS, AND J. E. GARRETT. 2000. Effects of Yeast Culture (Saccharomyces cerevisiae) on prepartum intake and postpartum intake and milk production of Jersey cows. Jour. Dairy Sci 83:123127

DENEV, S. A., Tz. PEEVA, P. RADULOVA, P. STANCHEVA, G. STAYKOVA, G. BEEV, P. TODOROVA and S. TCHOBANOVA, 2007. Yeast cultures in ruminant nutrition. Bulg. Jour. Agric. Sci. 13: 357-374 
DURAND, F. C. and H. DURAND. 2009. Probiotics in animal nutrition and health. France: Lallemand Animal Nutrition, Wageningen Academic Publishers. Beneficial Microbes 1(1): 39

El-Waziry, A.M. and H.R. Ibrahim, 2007. Effect of of yeast Saccharomyces cerevisiae on fiber digestion in sheep fed berseem (Trifolium alexandrinum) hay and cellulase activity. Aust. J. Basic Applied Sci., 1:379-385.

FARMER, C. G., R. C. COCHRAN, D. D. SIMMS, E. A. KLEVESAHL, T. A. WICKERSHAM and D. E. JOHNSON. 2001. The effects of several supplementation frequencies on forage use and the performance of beef cattle consuming dormant tallgrass prairie forage. Jour. of Anim. Sci. 79:2276-2285

FORTINA, R., L. M. BATTAGLINA, F. OPSI, S. TASSONE, M. RENNA AND A. MIMOSI. 2011. Effects of inactivated yeast culture on rumen fermentation and performance of mid-lactation dairy cows. Jour. Anim. \& Vet. Adv. 10(5):577-580

FULLER, M. F., N. J. BENEVENGA, S. P. LALL, K. J. MCCRACKEN, H. M. OMED, R. F .E. AXFORD and C. J. C. PHILLIPS. 2004. The Encyclopedia of Farm Animal Nutrition. UK: CABI Publishing 621pp

GUEDES, C. M. D. GONÇALVES, M.A.M. RODRIGUES, and A. DIAS-DA-SILVA. 2008. Effects of a Saccharomyces cerevisiae yeast on ruminal fermentation and fibre degradation of maize silages in cows. Anim. Feed Sci. \& Tech. 145: 27-40

HASSANEIN, S. M. AND N. K. SOLIMAN. 2010. Effect of Probiotic (Saccharomyces cerevisiae) adding to diets on intestinal microflora and performance of Hy-Line Layer Hens. Jour. American Sci 6(11):159-169

HELAL, F. I. S., and K. A. ABDEL-RAHMAN. 2010. Productive performance of lactating ewes fed diets supplementing with dry yeast and/or bentonite as feed additives. World Jour. Agric. Sci. 6(5): 489-498 
KŘIŽOVA, L., M. RICHTER, J. TŘINACTY, J. ŘIHA, and D. KUMPRECHTOVA. 2011. The effect of feeding live yeast cultures on ruminal $\mathrm{pH}$ and redox potential in dry cows as continuously measured by a new wireless device. Czech Jour. Anim. Sci. 56(1):37-45

LASLEY, J. F. 1981. Beef Cattle Production. USA: Prentice-Hall, Inc. p. 23

MAZZIA, M. AND N. WALKER. 2008. Using live yeast to unlock fiber potential. Alberta Beef Magazine Ltd., Nov. Series. France: Lallemand Animal Nutrition p. 1

MOSONI, P., F. C. DURAND, C. B. MAILLET and E. FORANO. 2007. Quantification by real-time PCR of cellulolytic bacteria in the rumen of sheep after supplementation of a forage diet with readily fermentable carbohydrates: effect of a yeast additive. Jour. Appl. Microbiol. 103 (2007): 2676-2685

NEWBOLD, C. J. and K. HILLMAN. 2004. Feed Supplements: Enzymes, Probiotics, Yeasts. Encyclopedia of Animal Science. Marcel Dekker, Inc. pp. 376-378

NEEBOLD, C. J. 1996. Probiotics for ruminants. Jour. Ann. Zootech 45: $329-335$

POND, W. G. AND A. W. BELL. 2005. Encyclopedia of Animal Science. Marcel Dekker, Inc. pp. 773-774

POPPI, D. P. and S. R. MCLENNAN. 1995. Protein and energy utilization by ruminants at pasture. Jour. of Anim. Sci. 73:278-290

ROBINSON, P. H. 2009. Yeast Products for Growing and Lactating Ruminants: A Literature Summary of Impacts on Rumen Fermentation and Performance. Cooperative Extension, University of California. pp. 1-13

SCANES, C. 2011. Fundamentals of Animal Science. Canada: Delmar Cengage Learning. 514pp

SOLAIMAN, S. G. 2010. Goat Science and Production. USA: Blackwell Publishing. 446pp 
TYLER, H. D. and M. E. ENSMINGER. 2006. Dairy Cattle Science. 4th Ed. Upper Saddle River, New Jersey: Pearson-Prentice Hall, Inc. p. 103

VINCENT, B. 2005. Farming meat goats: breeding, production and marketing. Australia: Landlinks Press. 289pp

WALLACE, R. J. 1994. Ruminal microbiology, biotechnology, and ruminant nutrition: progress and problems. Jour. Anim. Sci. 72:2992-3003

WOHLT, J. E., A. D. FINKELSTEIN, and C. H. CHUNG. 1991. Yeast culture to improve intake, nutrient digestibility, and performance by dairy cattle during early lactation. Jour. Dairy Sci. 74: 13951400

WOHLT, J. E., T. T. CORCIONE and P. K. ZAJAC. 1998. Effect of yeast on feed intake and performance of cows fed diets based on corn silage during early lactation. Jour. Dairy Sci 74: 13951400

ZIGGERS, D. 2011. A review: The benefits of yeast in ruminant nutrition. All About Feed: Int'l. Magazine An. Nutr. Proc. \& Feed Mgt. 2(1): 19-21 